\title{
We do not have evidence based methods for the treatment of cartilage defects in the knee
}

\author{
Jan P. Benthien - Manuela Schwaninger • \\ Peter Behrens
}

Received: 4 March 2010/Accepted: 7 September 2010/Published online: 18 November 2010

(C) Springer-Verlag 2010

\begin{abstract}
Purpose The aim of this study was to perform a systematic review of studies concerning current treatment of chondral defects of the knee.

Methods The relevance for evidence based data and for successful surgical treatment of cartilage defects was evaluated. From 56,098 evaluated studies, 133 studies could be further pursued. These supplied data concerning microfracturing, the osteochondral autograft transplantation system (OATS), the autologous chondrocyte implantation (ACI) and the matrix induced chondrocyte implantation (MACI). The modified Coleman Methodical Score (CMS) and the Level of Evidence (LOE) were applied to evaluate the quality.

Results In these studies, a total of 6,920 patients were reviewed with a median of 32 patients per study and a mean follow-up of 24 months. The mean CMS was 58 of 100 points. No study reached 100 points in the CMS. Three studies reached a level above 90. Ten studies were Level I, five studies reached Level II. Seven studies reached Level III, 111 studies Level IV. MRI scans to verify the clinical data were used by only 72 studies. The means in the modified CMS were for the different procedures as follows: ACI 58 points, MACI 57 points, microfracturing 68 points and OATS 50 points. 24 studies applied the Lysholm Score (LS) for clinical evaluation of cartilage surgery. All operative
\end{abstract}

\footnotetext{
J. P. Benthien $(\bowtie)$

Department of Orthopaedic Surgery, Division of Hip,

Knee and Prosthetics, University of Basel, Spitalstr. 21,

4031 Basel, Switzerland

e-mail: jbenthien@uhbs.ch

M. Schwaninger · P. Behrens

Department of Orthopaedic Surgery,

University of Luebeck, Luebeck, Germany
}

procedures yielded comparable improvements of the LS (n.s.) meaning that no operative procedure proved superior. Conclusion As the majority of studies evaluated by this review is insufficient for EBM purposes more coherent studies with LOE of I or II are needed. Co-relating the systems of CMS and LOE and validating the applied scores seems desirable.

Keywords Cartilage defects - Evidence based medicine . Knee injury $\cdot$ Repair

\section{Introduction}

Articular chondral defects find an increasing interest of orthopaedic surgeons because these lesions normally do not heal spontaneously and may predispose the joint to the development of secondary osteoarthritis.

This study was conducted to evaluate if any of today's most frequently applied and well documented articular resurfacing methods are evidence based. It is important for the funding health system to have objective criteria about the effectiveness of the respective methods as most decisions on funding are based on reliable data.

A number of different treatment options exist, none of which may be judged as the golden standard. Microfracturing, Osteochondral Autograft Transplantation System (OATS), Autologous Chondrocyte Transplantation (ACT) and Matrix Induced Chondrocyte Implantation (MACI) are the operative procedures for the treatment of articular defects which are very well documented by studies in the literature.There is much controversy to be found as to which treatment would be the most effective.

The multitude of studies treating this topic, the diversity of study designs and the high number of articles published 
are a reason for a comprehensive review with a systematic analysis. Some systematic reviews have been done on related subjects [59, 101].

Evidence Based Medicine (EBM) examines, evaluates and improves the quality of published data. It aims at creating scientifically sound standards for the physician. Important is the level of evidence with Level I and II studies yielding sufficient data from prospective randomised studies.

With articular resurfacing by the treatment of cartilage defects becoming increasingly popular and the public health system demanding evidence based facts especially for the different operative procedures existing in this field, a systematic review evaluating the existing material on the basis of evidence based medicine seems desirable.

\section{Materials and methods}

We performed a search strategy that involved clinical trials only. These should evaluate the treatment of cartilage defects in the human knee performing microfracturing, OATS, ACT and MACI, being currently the most commonly applied surgical techniques. A publication period from 2002 to 2007 was selected. The MEDLINE, EMBASE and Evidence Based Medicine Reviews were our databases. To extract the relevant articles, a search machine in the Ovid Linksolver was established. Online accessibility was one inclusion criterium. The other one was a text written in English, French or German. Abstracts in one of these languages were also included where the full paper was only available in a different language not meeting the selection criteria.

A total of 56,098 abstracts was screened by two independent scientists, 179 relevant publications could be selected by both. Of these, 133 studies could be extracted that met the following criteria: evaluating exclusively the operative techniques microfracturing, OATS, ACT and MACI, published between 2002 and 2007, available in the above databases, being online accessible, language in English, French or German, suitability for EBM evaluation.

Only papers evaluating the above operative procedures without any additional procedures werde considered as any additional procedure would influence the Level of Evidence.

\section{Coleman Methodical Score (CMS)}

The CMS as introduced first by Coleman et al. [21] was originally applied for grading clinical studies on patellar and Achilles tendinopathy. It was modified by Jakobsen et al. [59] changing the category of the postoperative rehabilitation protocol. The score has two parts and 10 criteria. A maximum score is 100 points, the minimum 0. A score of 100 means that the study excludes almost any bias, coincidence and other influences. Higher scores may support EBM.

Level of evidence (LOE) and lysholm score (LS)

The studies were also assessed by the use of the level-ofevidence-rating applied in the American Volume of The Journal of Bone and Joint Surgery since 2003. The Lysholm Score (LS) applied for cartilage injuries scores stair climbing, instability, squatting, limp, pain, support, locking and swelling. It was applied in 24 studies to compare clinical outcome of the different operative procedures as reflected in the studies.

Statistical methods

SSPS software version for Windows, version 17.0 (SSPS Inc, Chicago, Illinois) was applied to analyze the data. The continuous variables were reflected as medians. They were tested with the Shapiro-Wilkes-Test for their normal distribution. The Pearson correlation was used for normally distributed data. The Kruksal-Wallis-Test was used to test if the outcomes of different kinds of therapy differed significantly.

\section{Results}

56,098 articles corresponding to a MEDLINE, EMBASE and Evidence Based Medicine Reviews search conducted for the years 2002-2007 were reviewed.

133 relevant studies could be extracted. These reviewed 6,920 patients with a median of 32 patients per study and a mean follow-up of 24 months. There was an increase of $11 \%$ in the number of studies from 2002 to 2007 (Fig. 1). The most frequently described procedures in the single studies were ACI (36\%), OATS (30\%), MACI (14\%) and microfracturing (10\%). The combined studies compared ACI and OATS (4\%), OATS and microfracturing $(3 \%)$, MACI and microfracturing $(1 \%)$, ACI and microfracturing (1\%), ACI and MACI $(1 \%)$ (Fig. 2).

Ten publications reached a LOA of I, five studies reached Level II. Seven studies reached Level III, 111 studies Level IV (Fig. 3).

The CMS as modified by Jakobsen et al. [59] yielded only ten studies with a score of 80 or above (Fig. 4). No study reached a score of 100 . Three studies reached a score above 90. The mean CMS of all studies was 58 points. Applied to the operative techniques, microfraturing 
Fig. 1 The number of studies in relation to the years from 2002 to 2007 . An increase of $11 \%$ was noted

Fig. 2 Number of studies evaluating OATS, MACI, Microfracturing, ACI and a combination of procedures

Fig. 3 Number of studies grouped by their level of evidence
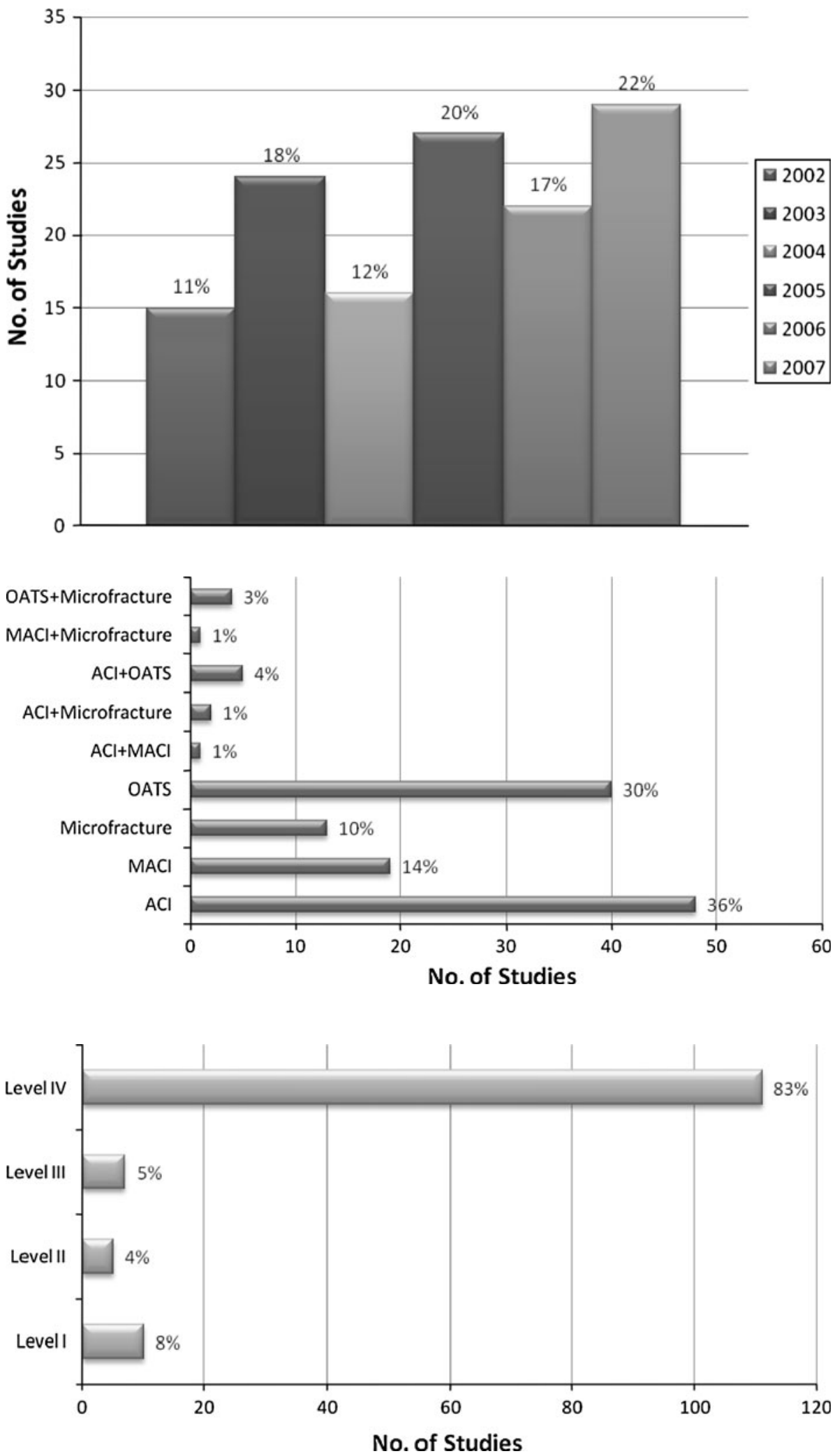

reached the highest modified CMS (mean = 68), followed by ACI $($ mean $=58)$, MACI $($ mean $=57)$ and OATS $($ mean $=50)($ Table 1$)$. To evaluate the operative results,
24 studies applied the Lysholm Score (LS) for cartilage injury. An increase in the LS is related to the success of the procedure. The MACI reached the highest increase with a 
Fig. 4 The modified Coleman methodological score score as reached by number of studies

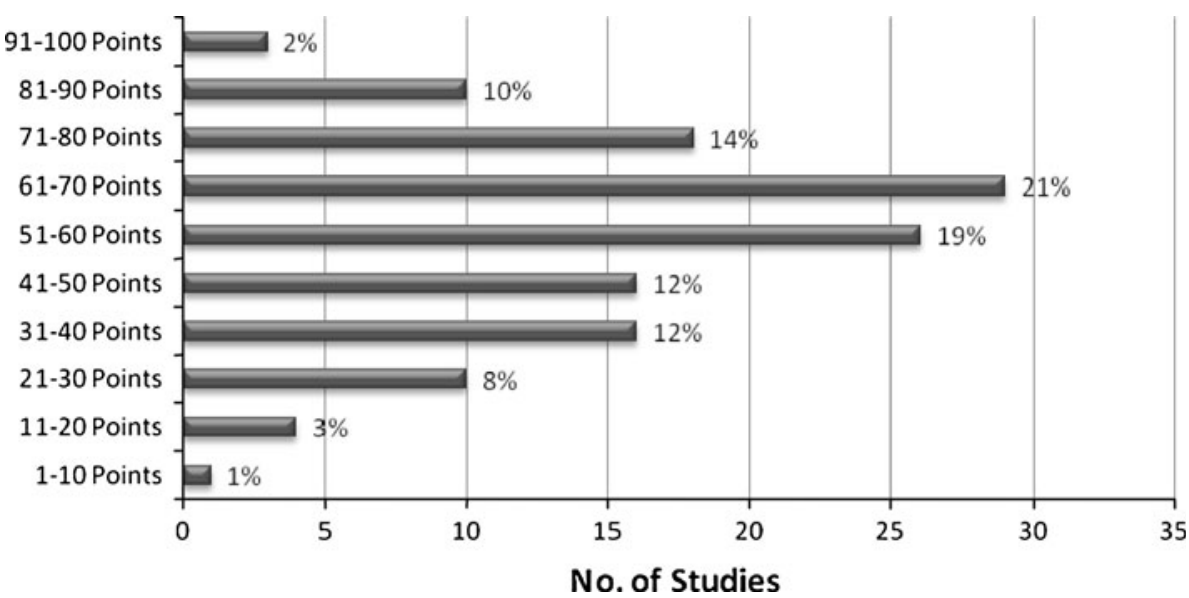

Table 1 Modified Coleman methodical score applied to the individual operative procedures

\begin{tabular}{lllllll}
\hline Type of therapy & Mean & SD & Median & Minimum & Maximum & $N$ \\
\hline ACI & 58 & 18 & 60 & 20 & 97 & 56 \\
MACI & 57 & 18 & 63 & 20 & 84 & 21 \\
Microfracture & 68 & 22 & 73 & 14 & 97 & 20 \\
OATS & 50 & 19 & 52 & 10 & 85 & 49 \\
\hline
\end{tabular}

median of 34 points, followed by OATS [32], microfracturing [32] and ACI [31]. There was no significant difference in the outcome of the procedures (n.s.) in the ONEWAY ANOVA).

Relating the studies applying the LS with their CMS yields a low correlation coefficient $(r=0.129)$ with high significance in the matched pair $t$-test $(P<0.001)$. MRI scans to verify the clinical data were applied in only 72 studies.

\section{Discussion}

The most important finding in this study was the following: although numerous studies examine results after cartilage surgery, no evidence based results could be clearly defined. The treatment of cartilage lesions is a problem in orthopaedic surgery as the self limiting of these lesions is not possible. Risks for developing a secondary arthritis are considerable, and for this reason the chondral lesions should be addressed. We have found that the general research about chondral lesions has increased by $11 \%$ from 2002 to 2007 which is not surprising giving the importance of this matter and its possible effects on lifestyle and activity. In order to help funding organisations such as insurance companies and public health systems to answer the following question: Is it possible to deduct from these studies the optimal treatment for the optimal patient? And is the Level of Evidence sufficient to underline this deduction?

The recommendation of the National Institute for Health and Clinical Excellence in London (NIHCE) from 2005 is based on four prospective randomised studies. Two compared $\mathrm{ACI}$ and OATS [11, 55], one compared ACI and microfracturing [67] and one compared different ways of ACI [13].

These studies demonstrated inconsistent and partially contradictory results which lead to discontinuation of funding of ACI by the British National Health System (NHS). This example shows the importance of Level I/II studies influencing public funding of a method.

Concerning the OATS technique, only 1 randomised controlled study by Bentley et al. [11] and the Level IV study by Hangody and Füles [47] were considered by the NIHCE as supportive in 2006. The Level I/II studies by Horas et al. [55] and Dozin et al. [25] were not considered. Studies comparing OATS and microfracturing like the prospective randomized one from Gudas et al. [39] were also not considered. More awareness should be raised to the funding boards about existing studies. This may be the future task of the respective medical boards.

One of the few studies comparing costs of articular resurfacing, Derrett et al. [23] reach the conclusion that average costs for ACI were lower than mosaicplasty. They recommend, however, more prospective studies to confirm this matter.

Generally, the MACI has a particulary poor data base: from 2002 to 2007, only one Level I study was found [8]. A prospective randomised study by Basad et al. [9] improves the data on MACI by comparing MACI to microfracturing.

Again, a difficult interpretation of the results due to different scores applied and partial incompatibility were noted, demonstrating that even Level I studies are difficult to compare and that the thorough review of the existing evidence based literature is important, even more so because these studies are comparatively scarce. The variance of the clinical tests applied is considerable: in the 
analyzed 133 studies, 27 different clinical scores were applied impairing comparability.

A common flaw in many studies is the selection bias with drop outs being neglected. The variety of clinical scores applied makes the studies difficult to compare. The Lysholm score for example is applied in only 24 studies. Even in these cases, it is not decided which operative method is preferable. This diversity of applied scores makes it difficult to refer the outcomes to certain operative methods, often impairing the decision making by the funding organisations.

No study reached a CMS of 100 , the average CMS was 58. This underlines the fact that most studies do not completely meet the criteria set by Coleman et al. [21] and Jakobsen [59].

Either these criteria are too strict to be applied for EBM in cartilage resurfing procedures or there are indeed too few studies that meet the criteria for EBM. The authors feel that the latter is more likely as the few studies reaching a higher CMS reach high LOEs.

The relationship between CMS and LOE has to the authors knowledge not yet been clearly established. It may be accepted that a CMS of 100 would support the highest LOE, and that a higher CMS would also support a high LOE. Our analysis looks at LOE and CMS as two different entities to evaluate the clinical significance of the screened studies. Not established is also the number of studies necessary to reach a strong EBM classification. For example, it remains uncertain if one study with a CMS of 100 and a LOE of I would suffice to support that the method is evidence based. This may be a serious flaw to the system of EBM. We could show in this study that decisions by health authorities and funding organisations are based on few EBM relevant studies, if at all. It is desirable that more prospective randomised studies are performed with comparable scores. This conclusion is supported by an article by Mithoefer et al. [101], where a similar conclusion regarding microfraturing alone is reached. We found that those studies applying the Lysholm Score for cartilage injuries could not provide a decision on a preferential method. There was also no co-relation between a higher Lysholm Score and the quality of a study, a fact also found by Jakobsen et al. [59]. Our results confirm that choosing and applying a commonly used score does not necessarily lead to a higher standard of EBM.

The studies researched in this review are quite heterogenous. For example, ACI is performed with a multitude of matrices and membranes, varying the original method. The OATS technique also varies quite considerably, in method and in definition. Even microfracturing as first introduced by Steadman is modified in many ways, using various membranes and matrices. It seems impossible to single out every factor that may influence the outcome of the respective research. In order to gain reliable EBM based data the methods of future studies should be coordinated and unified, preferably as suggested by their first author and his group, and performed by multi center research. As this is already standard for pharmaceutical research, the authors see no reason why this may not be applied in cartilage surgery.

\section{Conclusion}

There seems to be generally low methodical quality in the studies evaluated in this analysis. This may indicate that some caution is required when interpreting study results after surgical cartilage repair.

Definitive recommendations on which procedure to choose may not be given on the basis of the studies evaluated in this study. More attention should be paid to methodical quality when designing, performing, and reporting clinical studies. It is difficult to recommend a certain operative procedure because the pertaining literature is contradictory, prospective randomised trials are scarce in overall relation to the published literature and the applied scores are mostly unvalidated, too diverse and difficult to compare. This should change as decisions on funding by the public health system and the insurance companies tend to rely on prospective randomised studies.

\section{References}

\section{For the citation of the National Institute for Health and Clinical Excellence in London refer to www.nice.org.uk/ TA089}

1. Agneskirchner JD, Brucker P, Burkart A, Imhoff AB (2002) Large osteochondral defects of the femoral condyle: press-fit transplantation of the posterior femoral condyle (MEGAOATS). Knee Surg Sports Traumatol Arthrosc 10:160-168

2. Akgun I, Kesmezacar H, Ogut T, Kebudi A, Kanberoglu K (2005) Arthroscopic microfracture treatment for osteonecrosis of the knee. Arthroscopy 21:834-843

3. Andereya S, Maus U, Gavenis K, Gravius S, Stanzel S, MüllerRath R, Miltner O, Mumme T, Schneider U (2007) Treatment of patellofemoral cartilage defects utilizing a 3D collagen gel: twoyear clinical results. Z Orthop Unfall 145:139-145

4. Andres BM, Mears SC, Somel DS, Klug R, Wenz JF (2003) Treatment of osteoarthritic cartilage lesions with osteochondral autograft transplantation. Orthopedics 26:1121-1126

5. Bachmann G, Basad E, Lommel D, Steinmeyer J (2004) MRI in the follow-up of matrix-supported autologous chondrocyte transplantation (MACI) and microfracture. Radiologe 44:773-782

6. Bae DK, Yoon KH, Song SJ (2006) Cartilage healing after microfracture in osteoarthritic knees. Arthroscopy 22:367-374 
7. Bartlett W, Gooding CR, Carrington RW, Skinner JA, Briggs TW, Bentley G (2005) Autologous chondrocyte implantation at the knee using a bilayer collagen membrane with bone graft. A preliminary report. J Bone Joint Surg Br 87:330-332

8. Bartlett W, Skinner JA, Gooding CR, Carrington RW, Flanagan AM, Briggs TW, Bentley G (2005) Autologous chondrocyte implantation versus matrix-induced autologous chondrocyte implantation for osteochondral defects of the knee: a prospective, randomised study. J Bone Joint Surg Br 87:640-645

9. Basad E, Ishaque B, Bachmann G, Stürz H, Steinmeyer J (2010) Matrix induced chondrocyte implantation versus microfracture in the reatment of cartilage defects of the knee: a 2-year randomised study. Knee Surg Sports Traumatol Arthrosc 18:519-527

10. Behrens P, Bitter T, Kurz B, Russlies M (2006) Matrix-associated autologous chondrocyte transplantation/implantation (MACT/MACI) -5- year follow-up. Knee 13:194-202

11. Bentley G, Biant LC, Carrington RW, Akmal M, Goldberg A, Williams AM, Skinner JA, Pringle J (2003) A prospective, randomised comparison of autologous chondrocyte implantation versus mosaicplasty for osteochondral defects in the knee. J Bone Joint Surg Br 85:223-230

12. Briggs TW, Mahroof S, David LA, Flannelly J, Pringle J, Bayliss M (2003) Histological evaluation of chondral defects after autologous chondrocyte implantation of the knee. J Bone Joint Surg Br 85:1077-1083

13. Brittberg $M$, Peterson L, Sjögren-Jansson E, Tallheden $T$, Lindahl A (2003) Articular cartilage engineering with autologous chondrocyte transplantation. A review of recent developments. J Bone Joint Surg Am 85-A:109-115

14. Browne JE, Anderson AF, Arciero R, Mandelbaum B, Moseley JB Jr, Micheli LJ, Fu F, Erggelet C (2005) Clinical outcome of autologous chondrocyte implantation at 5 years in US subjects. Clin Orthop Relat Res 436:237-245

15. Brucker R, Agneskirchner JD, Burkart A, Imhoff AB (2002) Mega-oats. Technique and results. Unfallchirurg 105:443-449

16. Burkart A, Imhoff AB (2002) Treatment of articular cartilage defects with the autologous chondrocyte transplantation (ACT). Surg Technol Int 10:255-260

17. Caumo F, Russo A, Faccioli N, Vecchini E, Costa A, Ricci M, Pozzi Mucelli R (2007) Autologous chondrocyte implantation: prospective MRI evaluation with clinical correlation. Radiol Med (Torino) 112:722-731

18. Chanlalit C, Kasemkijwattanamd C, Varavit V (2007) Autologous chondrocyte implantation for traumatic large cartilage defect. J Med Assoc Thai 90:1435-1444

19. Cherubino P, Grassi FA, Bulgheroni P, Ronga M (2003) Autologous chondrocyte implantation using a bilayer collagen membrane: a preliminary report. J Orthop Surg 11:10-15

20. Chow JC, Hantes ME, Houle JB, Zalavras CG (2004) Arthroscopic autogenous osteochondral transplantation for treating knee cartilage defects: a 2- to 5-year follow-up study. Arthroscopy 20:681-690

21. Coleman BD, Khan KM, Maffulli N, Cook JL, Wark JD (2000) Studies of surgical outcome after patellar tendinopathy: clinical significance of methodological deficiencies and guidelines for future studies. Scand J Med Sci Sports 10:2-11

22. Delcogliano A, Caporaso A, Menghi A, Rinonapoli G, Chiossi S (2002) Results of autologous osteochondral grafts in chondral lesions of the knee. Minerva Chir 57:273-281

23. Derrett S, Stokes EA, James M, Bartlett W, Bentley G (2005) Cost and health status analysis after autologous chondrocyte implantation and mosaicplasty: a retrospective comparison. Int $\mathbf{J}$ Technol Assess Health Care 2:359-367

24. Dorotka R, Kotz R, Trattnig S, Nehrer S (2004) Mid-term results of autologous chondrocyte transplantation in knee and ankle. A one- to sixyear follow-up study. Z Rheumatol 63:385-392
25. Dozin B, Malpeli M, Cancedda R, Bruzzi P, Calcagno S, Molfetta L, Priano F, Kon E, Marcacci M (2005) Comparative evaluation of autologous chondrocyte implantation and mosaicplasty: a multicentered randomized clinical trial. Clin J Sport Med 15:220-226

26. Drobnic M, Kregar-Velikonja N, Radosavljevic D, Gorensek M, Koritnik B, Malicev E, Wozniak G, Jeras M, Knezevic M (2002) The outcome of autologous chondrocyte transplantation treatment of cartilage lesions in the knee. Cell Mol Biol Lett $7: 361-363$

27. Emmerson BC, Görtz S, Jamali AA, Chung C, Amiel D, Bugbee WD (2007) Fresh osteochondral allografting in the treatment of osteochondritis dissecans of the femoral condyle. Am J Sports Med 35:907-914

28. Farr J (2007) Autologous chondrocyte implantation improves patellofemoral cartilage treatment outcomes. Clin Orthop Relat Res 463:187-194

29. Ferruzzi A, Calderoni P, Grigolo B, Gualtieri G (2004) Autologous chondrocytes implantation: indications and results in the treatment of articular cartilage lesions of the knee. Chir Organi Mov 89:125-134

30. Fu FH, Zurakowski D, Browne JE, Mandelbaum B, Erggelet C, Moseley JB Jr, Anderson AF, Micheli LJ (2005) Autologous chondrocyte implantation versus debridement for treatment of full-thickness chondral defects of the knee: an observational cohort study with 3-year follow-up. Am J Sports Med 33: 1658-1666

31. Gaweda K, Modrzewski K, Godlewski P, Walawski J, Krzyzanowski W (2002) Repair of focal chondral lesions of femoral condyles treated with osteochondral autografts. Chir Narzadow Ruchu Ortop Pol 67:247-253

32. Glaser C, Tins BJ, Trumm CG, Richardson JB, Reiser MF, McCall IW (2007) Quantitative 3D MR evaluation of autologous chondrocyte implantation in the knee: feasibility and initial results. Osteoarthritis Cartilage 15:798-807

33. Gobbi A, Nunag P, Malinowski K (2005) Treatment of full thickness chondral lesions of the knee with microfracture in a group of athletes. Knee Surg Sports Traumatol Arthrosc 13: 213-221

34. Gooding CR, Bartlett W, Bentley G, Skinner JA, Carrington R, Flanagan A (2006) A prospective, randomised study comparing two techniques of autologous chondrocyte implantation for osteochondral defects in the knee: periosteum covered versus type I/III collagen covered. Knee 13:203-210

35. Gross AE, Aubin P, Cheah HK, Davis AM, Ghazavi MT (2002) A fresh osteochondral allograft alternative. J Arthroplasty 17:50-53

36. Gross AE, Shasha N, Aubin P (2005) Long-term followup of the use of fresh osteochondral allografts for posttraumatic knee defects. Clin Orthop Relat Res 435:79-87

37. Gudas R (2002) Autologous osteochondral transplantation (mosaicplasty) in the treatment of femoral condyle defects. Medicina (Kaunas) 38:52-57

38. Gudas R (2004) Clinical results after articular cartilage injury revision surgeries. Medicina (Kaunas) 40:315-319

39. Gudas R, Stankevicius E, Monastyreckiene E, Pranys D, Kalesinskas RJ (2006) Osteochondral autologous transplantation versus microfracture for the treatment of articular cartilage defects in the knee joint in athletes. Knee Surg Sports Traumatol Arthrosc 14:834-842

40. Gudas R, Kalesinskas RJ, Kimtys V, Stankevicius E, Toliusis V, Bernotavicius G, Smailys A (2005) A prospective randomized clinical study of mosaic osteochondral autologous transplantation versus microfracture for the treatment of osteochondral defects in the knee joint in young athletes. Arthroscopy 21:1066-1075 
41. Gudas R, Kalesinskas RJ, Monastyreckiene E, Valanciūte A, Trumpickas V (2003) Osteochondral transplantation (mosaicplasty) in the treatment of knee joint cartilage defects. Medicina (Kaunas) 39:469-475

42. Gudas R, Kunigiskis K, Kalensinskas RJ (2002) Long-term follow-up of osteochondrosis dissecans. Medicina (Kaunas) 38:284-288

43. Haddo O, Mahroof S, Higgs D, David L, Pringle J, Bayliss M, Cannon SR, Briggs TW (2004) The use of chondrogide membrane in autologous chondrocyte implantation. Knee 11:51-55

44. Halbrecht JL, Klick BC (2006) Improvement in bone homeostasis following autologous chondrocyte implantation of the knee. Orthopedics 29:61-69

45. Handl M, Trc T, Hanus M, Stastný E, Fricová-Poulová M, Neuwirth J, Adler J, Havranová D, Varga F (2006) Therapy of severe chondral defects of the patella by autologous chondrocyte implantation. Acta Chir Orthop Traumatol Cech 73:373-379

46. Hangody L, Ráthonyi GK, Duska Z, Vásárhelyi G, Füles P, Módis L (2004) Autologous osteochondral mosaicplasty. Surgical technique. J Bone Joint Surg Am 86-A:65-72

47. Hangody L, Füles P (2003) Autologous osteochondral mosaicplasty for the treatment of full-thickness defects of weightbearing joints: ten years of experimental and clinical experience. J Bone Joint Surg Am 85-A:25-32

48. Henderson I, Francisco R, Oakes B, Cameron J (2005) Autologous chondrocyte implantation for treatment of focal chondral defects of the knee-a clinical, arthroscopic, MRI and histologic evaluation at 2 years. Knee 12:209-216

49. Henderson IJ, Tuy B, Connell D, Oakes B, Hettwer WH (2003) Prospective clinical study of autologous chondrocyte implantation and correlation with MRI at three and 12 months. J Bone Joint Surg Br 85:1060-1066

50. Henderson IJ, Lavigne P (2006) Periosteal autologous chondrocyte implantation for patellar chondral defect in patients with normal and abnormal patellar tracking. Knee 13:274-279

51. Henderson I, Tuy B, Oakes B (2004) Reoperation after autologous chondrocyte implantation. Indications and findings. J Bone Joint Surg Br 86:205-211

52. Henderson IJ, Tuy B, Connell D, Oakes B, Hettwer WH (2003) Prospective clinical study of autologous chondrocyte implantation and correlation with MRI at three and 12 months. J Bone Joint Surg Br 85:1060-1066

53. Henderson IJ, Lavigne P (2006) Periosteal autologous chondrocyte implantation for patellar chondral defect in patients with normal and abnormal patellar tracking. Knee 13:274-279

54. Herber S, Runkel M, Pitton MB, Kalden P, Thelen M, Kreitner KF (2003) Indirect MR-arthrography in the follow up of autologous osteochondral transplantation. Rofo 175:226-233

55. Horas U, Pelinkovic D, Herr G, Aigner T, Schnettler R (2003) Autologous chondrocyte implantation and osteochondral cylinder transplantation in cartilage repair of the knee joint. A prospective, comparative trial. J Bone Joint Surg Am 85-A:185-192

56. Horas U, Schnettler R (2003) Chondral defects of the knee treated by transplantation of autogenous osteochondral plugs. Orthop Traumatol 10:220-234

57. Huang H, Yin Q, Zhang Y, Zhang Y, Cao Z, Li J, Liu J (2002) Mosaicplasty osteochondral grafting to repair cartilaginous defects under arthroscopy. Zhonghua Wai Ke Za Zhi 40: 662-664

58. Jakob RP, Franz T, Gautier E, Mainil-Varlet P (2002) Autologous osteochondral grafting in the knee: indication, results, and reflections. Clin Orthop Relat Res 401:170-184

59. Jakobsen RB, Engebretsen L, Slauterbeck JR (2005) An analysis of the quality of cartilage repair studies. J Bone Joint Surg Am 87:2232-2239
60. Jamali AA, Emmerson BC, Chung C, Convery FR, Bugbee WD (2005) Fresh osteochondral allografts. Clin Orthop Relat Res 437:176-185

61. Jobanputra P, Parry D, Fry-Smith A, Burls A (2001) Effectiveness of autologous chondrocyte transplantation for hyaline cartilage defects in knees: a rapid and systematic review. Health Technol Assess 5:1-57

62. Karataglis D, Green MA, Learmonth DJ (2006) Autologous osteochondral transplantation for the treatment of chondral defects of the knee. Knee 13:32-35

63. Karataglis D, Learmonth DJ (2005) Management of big osteochondral defects of the knee using osteochondral allografts with the MEGA-OATS technique. Knee 12:389-393

64. Kish G, Hangody L (2004) A prospective, randomised comparison of autologous chondrocyte implantation versus mosaicplasty for osteochondral defects in the knee. J Bone Joint Surg Br 86:619

65. Klinger HM, Lorenz F, Otte S, Beyer J (2002) Treatment of cartilage defects with autologous osteochondral grafts in the knee joint. Eur J Orthop Surg Traumatol 12:26-29

66. Knutsen G, Drogset JO, Engebretsen L, Grøntvedt T, Isaksen V, Ludvigsen TC, Roberts S, Solheim E, Strand T, Johansen O (2007) A randomized trial comparing autologous chondrocyte implantation with microfracture. Findings at five years. J Bone Joint Surg Am 89:2105-2112

67. Knutsen G, Engebretsen L, Ludvigsen TC, Drogset JO, Grøntvedt T, Solheim E, Strand T, Roberts S, Isaksen V, Johansen O (2004) Autologous chondrocyte implantation compared with microfracture in the knee. A randomized trial. J Bone Joint Surg Am 486-A:455-464

68. Kocher MS, Steadman JR, Briggs KK, Sterett WI, Hawkins RJ (2004) Reliability, validity, and responsiveness of the Lysholm knee scale for various chondral disorders of the knee. J Bone Joint Surg Am 86-A:1139-1145

69. Koulalis D, Schultz W, Heyden M, König F (2004) Autologous osteochondral grafts in the treatment of cartilage defects of the knee joint. Knee Surg Sports Traumatol Arthrosc 12: 329-334

70. Kreuz PC, Steinwachs M, Erggelet C, Lahm A, Krause S, Ossendorf C, Meier D, Ghanem N, Uhl M (2007) Importance of sports in cartilage regeneration after autologous chondrocyte implantation: a prospective study with a 3-year follow-up. Am J Sports Med 35:1261-1268

71. Kreuz PC, Steinwachs MR, Erggelet C, Krause SJ, Konrad G, Uhl M, Südkamp N (2006) Results after microfracture of fullthickness chondral defects in different compartments in the Knee. Osteoarthritis Cartilage 14:1119-1125

72. Kreuz PC, Erggelet C, Steinwachs MR, Krause SJ, Lahm A, Niemeyer P, Ghanem N, Uhl M, Südkamp N (2006) Is microfracture of chondral defects in the knee associated with different results in patients aged 40 years or younger? Arthroscopy 11:1180-1186

73. Krishnan SP, Skinner JA, Carrington RW, Flanagan AM, Briggs TW, Bentley G (2006) Collagen-covered autologous chondrocyte implantation for osteochondritis dissecans of the knee: twoto seven-year results. J Bone Joint Surg Br 88:203-205

74. Lahav A, Burks RT, Greis PE, Chapman AW, Ford GM, Fink BP (2006) Clinical outcomes following osteochondral autologous transplantation (OATS). J Knee Surg 19:169-173

75. Lange J, Follak N, Nowotny T, Merk H (2006) Results of SaluCartilage implantation for stage IV chondral defects in the knee joint area. Unfallchirurg 109:193-199

76. LaPrade RF (2003) Autologous chondrocyte implantation was superior to mosaicplasty for repair of articular cartilage defects in the knee at one year. J Bone Joint Surg Am 85-A:2259 
77. Lehman RC, Perry CR (2003) Modified osteochondral autograft implantation for full- thickness articular cartilage lesions. Arthroscopy 19:318-320

78. Liebau C, Baltzer AW, Arnold J, Bartmann T, Behnke B, Koch H, Merk H (2003) Experiences after 150 cartilage-bone-transplantations of the knee: a prospective analysis of the results. Zentralbl Chir 128:511-516

79. Lubowitz JH, Appleby D, Centeno JM, Woolf SK, Reid JB 3rd (2007) The relationship between the outcome of studies of autologous chondrocyte implantation and the presence of commercial funding. Am J Sports Med 35:1809-1816

80. Ma HL, Hung SC, Wang ST, Chang MC, Chen TH (2004) Osteochondral autografts transfer for post-traumatic osteochondral defect of the knee-2 to 5 years follow-up. Injury 35 : $1286-1292$

81. Mandelbaum B, Browne JE, Fu F, Micheli LJ, Moseley JB Jr, Erggelet C, Anderson AF (2007) Treatment outcomes of autologous chondrocyte implantation for full-thickness articular cartilage defects of the trochlea. Am J Sports Med 35:915-921

82. Manfredini M, Zerbinati F, Gildone A, Faccini R (2007) Autologous chondrocyte implantation: a comparison between an open periosteal-covered and an arthroscopic matrix-guided technique. Acta Orthop Belg 73:207-218

83. Marcacci M, Berruto M, Brocchetta D, Delcogliano A, Ghinelli D, Gobbi A, Kon E, Pederzini L, Rosa D, Sacchetti GL, Stefani G, Zanasi S (2005) Articular cartilage engineering with Hyalograft C: 3-year clinical results. Clin Orthop Relat Res 435: 96-105

84. Marcacci M, Kon E, Delcogliano M, Filardo G, Busacca M, Zaffagnini S (2007) Arthroscopic autologous osteochondral grafting for cartilage defects of the knee: prospective study results at a minimum 7-year follow-up. Am J Sports Med 35:2014-2021

85. Marcacci M, Kon E, Zaffagnini S, Filardo G, Delcogliano M, Neri MP, Iacono F, Hollander AP (2007) Arthroscopic second generation autologous chondrocyte implantation. Knee Surg Sports Traumatol Arthrosc 15:610-619

86. Marcacci M, Kon E, Zaffagnini S, Iacono F, Neri MP, Vascellari A, Visani A, Russo A (2005) Multiple osteochondral arthroscopic grafting (mosaicplasty) for cartilage defects of the knee: prospective study results at 2-year follow-up. Arthroscopy 21:462-470

87. Marder RA, Hopkins G Jr, Timmerman LA (2005) Arthroscopic microfracture of chondral defects of the knee: a comparison of two postoperative treatments. Arthroscopy 21:152-158

88. Marlovits S, Kutscha-Lissberg F, Aldrian S, Resinger C, Singer P, Zeller P, Vécsei V (2004) Autologous chondrocyte transplantation for the treatment of articular cartilage defects in the knee joint. Techniques and results. Radiologe 44:763-772

89. Matsunaga D, Akizuki S, Takizawa T, Yamazaki I, Kuraishi J (2007) Repair of articular cartilage and clinical outcome after osteotomy with microfracture or abrasion arthroplasty for medial gonarthrosis. Knee 14:465-471

90. McCulloch PC, Kang RW, Sobhy MH, Hayden JK, Cole BJ (2007) Prospective evaluation of prolonged fresh osteochondral allograft transplantation of the femoral condyle: minimum 2-year follow-up. Am J Sports Med 35:411-420

91. Meenen NM, Rischke B (2003) Autogenous osteochondral transplantation (AOT) for cartilaginous defects of the femoral condyle. Oper Orthop Traumatol 15:38-56

92. Micheli LJ, Moseley JB, Anderson AF, Browne JE, Erggelet C, Arciero R, Fu FH, Mandelbaum BR (2006) Articular cartilage defects of the distal femur in children and adolescents: treatment with autologous chondrocyte implantation. J Pediatr Orthop 26:455-460
93. Miller BS, Steadman JR, Briggs KK, Rodrigo JJ, Rodkey WG (2004) Patient satisfaction and outcome after microfracture of the degenerative knee. J Knee Surg 17:13-17

94. Minas T, Bryant T (2005) The role of autologous chondrocyte implantation in the patellofemoral joint. Clin Orthop Relat Res 436:30-39

95. Miniaci A, Tytherleigh-Strong G (2007) Fixation of unstable osteochondritis dissecans lesions of the knee using arthroscopic autogenous osteochondral grafting (mosaicplasty). Arthroscopy 23:845-851

96. Mithöfer K, Minas T, Peterson L, Yeon H, Micheli LJ (2005) Functional outcome of knee articular cartilage repair in adolescent athletes. Am J Sports Med 33:1147-1153

97. Mithöfer K, Peterson L, Mandelbaum BR, Minas T (2005) Articular cartilage repair in soccer players with autologous chondrocyte transplantation: functional outcome and return to competition. Am J Sports Med 33:1639-1646

98. Mithoefer K, Williams RJ 3rd, Warren RF, Potter HG, Spock CR, Jones EC, Wickiewicz TL, Marx RG (2006) Chondral resurfacing of articular cartilage defects in the knee with the microfracture technique. Surgical technique. J Bone Joint Surg Am 88:294-304

99. Mithoefer K, Williams RJ 3rd, Warren RF, Potter HG, Spock CR, Jones EC, Wickiewicz TL, Marx RG (2005) The microfracture technique for the treatment of articular cartilage lesions in the knee. A prospective cohort study. J Bone Joint Surg Am 87:1911-1920

100. Mithoefer K, Williams RJ 3rd, Warren RF, Wickiewicz TL, Marx RG (2006) High-impact athletics after knee articular cartilage repair: a prospective evaluation of the microfracture technique. Am J Sports Med 34:1413-1418

101. Mithoefer K, McAdams T, Williams RJ, Kreuz PC, Mandelbaum BR (2009) Clinical efficacy of the microfracture technique for articular cartilage repair in the knee: an evidence based systematic analysis. Am J Sports Med 37:2053-2063

102. Moriya T, Wada Y, Watanabe A, Sasho T, Nakagawa K, MainilVarlet P, Moriya H (2007) Evaluation of reparative cartilage after autologous chondrocyte implantation for osteochondritis dissecans: histology, biochemistry, and MR imaging. J Orthop Sci 12:265-273

103. Nakagawa Y, Matsusue Y, Suzuki T, Kuroki H, Nakamura T (2004) Osteochondral grafting for cartilage defects in the patellar grooves of bilateral knee joints. Arthroscopy 20:32-38

104. Nakagawa Y, Suzuki T, Kuroki H, Kobayashi M, Okamoto Y, Nakamura T (2007) The effect of surface incongruity of grafted plugs in osteochondral grafting: a report of five cases. Knee Surg Sports Traumatol Arthrosc 15:591-596

105. Nehrer S, Domayer S, Dorotka R, Schatz K, Bindreiter U, Kotz $\mathrm{R}$ (2006) Three-year clinical outcome after chondrocyte transplantation using a hyaluronan matrix for cartilage repair. Eur $\mathrm{J}$ Radiol 57:3-8

106. Niemeyer P, Kreuz PC, Steinwachs M, Köstler W, Mehlhorn A, Kraft N, Südkamp NP (2007) Technical note: the "double eye" technique as a modification of autologous chondrocyte implantation for the treatment of retropatellar cartilage defects. Knee Surg Sports Traumatol Arthrosc 15:1461-1468

107. Niemeyer P, Kreuz PC, Steinwachs M, Südkamp NP (2007) Operative treatment of cartilage lesions in the knee joint. Sportverletz Sportschaden 21:41-50

108. Ochi M, Uchio Y, Kawasaki K, Wakitani S, Iwasa J (2002) Transplantation of cartilage-like tissue made by tissue engineering in the treatment of cartilage defects of the knee. J Bone Joint Surg Br 84:571-578

109. Orljanski W, Aghayev E, Zazirnyj I, Schabus R (2005) Treatment of focal articular cartilage lesions of the knee with 
autogenous osteochondral grafts. Acta Chir Orthop Traumatol Cech 72:246-249

110. Ossendorf C, Kaps C, Kreuz PC, Burmester GR, Sittinger M, Erggelet C (2007) Treatment of posttraumatic and focal osteoarthritic cartilage defects of the knee with autologous polymerbased three-dimensional chondrocyte grafts: 2-year clinical results. Arthritis Res Ther 9:R41

111. Ossendorf C, Kreuz PC, Steinwachs MR, Erggelet C (2007) Autologous chondrocyte implantation for the treatment of large full-thickness cartilage lesions of the knee. Saudi Med J 28:1251-1256

112. Oztürk A, Ozdemir MR, Ozkan Y (2006) Osteochondral autografting (mosaicplasty) in grade IV cartilage defects in the knee joint: 2- to 7-year results. Int Orthop 30:200-204

113. Pavesio A, Abatangelo G, Borrione A, Brocchetta D, Hollander AP, Kon E, Torasso F, Zanasi S, Marcacci M (2003) Hyaluronan-based scaffolds (Hyalograft $\mathrm{C}$ ) in the treatment of knee cartilage defects: preliminary clinical findings. Novartis Found Symp 249:203-217

114. Peterson L (2006) ACI surgical technique and results at 2-10 years. In: Zanasi S, Brittberg M, Marcacci M (eds) Basic science, clinical repair and reconstruction of articular cartilage defects: current status and prospects. Timeo, Bologna, pp 325-330

115. Peterson L, Minas T, Brittberg M, Lindahl A (2003) Treatment of osteochondritis dissecans of the knee with autologous chondrocyte transplantation: results at two to ten years. J Bone Joint Surg Am 85-A:17-24

116. Podskubka A, Povýsil C, Kubes R, Sprindrich J, Sedlácek R (2006) Treatment of deep cartilage defects of the knee with autologous chondrocyte transplantation on a hyaluronic Acid ester scaffolds (Hyalograft C). Acta Chir Orthop Traumatol Cech 73:251-263

117. Robert H, Bahuaud J, Kerdiles N, Passuti N, Capelli M, Pujol JP, Hartman D, Locker B, Hulet C, Hardy P, Coudane H, Rochverger A, Francheschi JP et al.; Société Française d'Arthroscopie (2007) Treatment of deep cartilage defects in the knee with autologous chondrocyte transplantation: a review of 28 cases. Rev Chir Orthop Reparatrice Appar Mot 93:701-709

118. Roberts S, McCall IW, Darby AJ, Menage J, Evans H, Harrison PE, Richardson JB (2003) Autologous chondrocyte implantation for cartilage repair: monitoring its success by magnetic resonance imaging and histology. Arthritis Res Ther 5:R60-R73

119. Robertson WB, Fick D, Wood DJ, Linklater JM, Zheng MH, Ackland TR (2007) MRI and clinical evaluation of collagencovered autologous chondrocyte implantation (CACI) at two years. Knee 14:117-127

120. Ronga M, Grassi FA, Bulgheroni P (2004) Arthroscopic autologous chondrocyte implantation for the treatment of a chondral defect in the tibial plateau of the knee. Arthroscopy 20:79-84

121. Rose T, Lill H, Hepp P, Josten C (2005) Autologous osteochondral mosaicplasty for treatment of a posttraumatic defect of the lateral tibial plateau: a case report with two-year follow-up. J Orthop Trauma 19:217-222

122. Schneider U, Andereya S (2003) First results of a prospective randomized clinical trial on traditional chondrocyte transplantation vs CaReS-Technology. Z Orthop Ihre Grenzgeb 141:496-497

123. Scorrano A, Biggi F, Turi G (2004) Autologous chondrocyte implantation for focal cartilage defects in athletes: Histology and second-look arthroscopy. J Orthop Traumatol 5:98-105

124. Sharpe JR, Ahmed SU, Fleetcroft JP, Martin R (2005) The treatment of osteochondral lesions using a combination of autologous chondrocyte implantation and autograft: three-year follow-up. J Bone Joint Surg Br 87:730-735
125. Shasha N, Aubin PP, Cheah HK, Davis AM, Agnidis Z, Gross AE (2002) Long-term clinical experience with fresh osteochondral allografts for articular knee defects in high demand patients. Cell Tissue Bank 3:175-182

126. Shasha N, Krywulak S, Backstein D, Pressman A, Gross AE (2003) Long-term follow-up of fresh tibial osteochondral allografts for failed tibial plateau fractures. J Bone Joint Surg Am 85-A:33-39

127. Spak TR, Teitge RA (2006) Fresh osteochondral allografts for patellofemoral arthritis: long-term followup. Clin Orthop Relat Res 444:193-200

128. Steadman JR, Briggs KK, Rodrigo JJ, Kocher MS, Gill TJ, Rodkey WG (2003) Outcomes of microfracture for traumatic chondral defects of the knee: average 11-year follow-up. Arthroscopy 19:477-484

129. Steadman JR, Miller BS, Karas SG, Schlegel TF, Briggs KK, Hawkins RJ (2003) The microfracture technique in the treatment of full-thickness chondral lesions of the knee in National Football League players. J Knee Surg 16:83-86

130. Steinwachs M, Kreuz PC (2007) Autologous chondrocyte implantation in chondral defects of the knee with a type I/III collagen membrane: a prospective study with a 3-year followup. Arthroscopy 23:381-387

131. Takahashi T, Tins B, McCall IW, Richardson JB, Takagi K, Ashton K (2006) MR appearance of autologous chondrocyte implantation in the knee: correlation with the knee features and clinical outcome. Skeletal Radiol 35:16-26

132. Tins BJ, McCall IW, Takahashi T, Cassar-Pullicino V, Roberts S, Ashton B, Richardson J (2005) Autologous chondrocyte implantation in knee joint: MR imaging and histologic features at 1- year follow-up. Radiology 234:501-508

133. Trattnig S, Ba-Ssalamah A, Pinker K, Plank C, Vecsei V, Marlovits S (2005) Matrix-based autologous chondrocyte implantation for cartilage repair: noninvasive monitoring by high-resolution magnetic resonance imaging. Magn Reson Imaging 23:779-787

134. Trattnig S, Pinker K, Krestan C, Plank C, Millington S, Marlovits S (2006) Matrix-based autologous chondrocyte implantation for cartilage repair with Hyalograft C: two-year follow-up by magnetic resonance imaging. Eur J Radiol 57:9-15

135. Trzaska T, Rapala K (2003) Osteochondral transplantation in the treatment of knee joint cartilage defects. Polski Przeglad Chirurgiczny 75:154-163

136. Ueblacker P, Burkart A, Imhoff AB (2004) Retrograde cartilage transplantation on the proximal and distal tibia. Arthroscopy 20:73-78

137. Vanlauwe J, Almqvist F, Bellemans J, Huskin JP, Verdonk R, Victor J (2007) Repair of symptomatic cartilage lesions of the knee: the place of autologous chondrocyte implantation. Acta Orthop Belg 73:145-158

138. Vasara AI, Nieminen MT, Jurvelin JS, Peterson L, Lindahl A, Kiviranta I (2005) Indentation stiffness of repair tissue after autologous chondrocyte transplantation. Clin Orthop Relat Res 433:233-242

139. Visna P, Pasa L, Cizmár I, Hart R, Hoch J (2004) Treatment of deep cartilage defects of the knee using autologous chondrograft transplantation and by abrasive techniques-a randomized controlled study. Acta Chir Belg 104:709-714

140. Visna P, Pasa L, Hart R, Kocis J, Cizmár I, Adler J (2003) Treatment of deep chondral defects of the knee using autologous chondrocytes cultured on a support-results after one year. Acta Chir Orthop Traumatol Cech 70:356-362

141. Visna P, Adler J, Pasa L, Kocis J, Cizmar I, Horky D (2003) Autologous chondrocyte transplantation for the treatment of 
articular defects of the knee. Scripta Medica Facultatis Medicae Universitatis Brunensis Masarykianae 76:241-250

142. Wada Y, Watanabe A, Yamashita T, Isobe T, Moriya H (2003) Evaluation of articular cartilage with 3D-SPGR MRI after autologous chondrocyte implantation. J Orthop Sci 8:514-517

143. Wang CJ (2002) Treatment of focal articular cartilage lesions of the knee with autogenous osteochondral graftsA 2- to 4-year follow-up study. Arch Orthop Trauma Surg 122:169-172

144. Williams RJ 3rd, Harnly HW (2007) Microfracture: indications, technique, and results. Instr Course Lect 56:419-428
145. Yates JW Jr (2003) The effectiveness of autologous chondrocyte implantation for treatment of full-thickness articular cartilage lesions in workers' compensation patients. Orthopedics 26:295-300

146. Zheng MH, Willers C, Kirilak L, Yates P, Xu J, Wood D, Shimmin A (2007) Matrix-induced autologous chondrocyte implantation (MACI): biological and histological assessment. Tissue Eng 13:737-746 